\title{
Diurnal Wind Characteristics in and around Chisapani Confluence of Karnali River in Mid-Western Nepal
}

\author{
Sangeeta Maharjan and Ram P. Regmi \\ National Atmospheric Resource and Environmental Research Laboratory (NARERL) \\ Central Department of Physics, Tribhuvan University, Kirtipur, Kathmandu, Nepal. \\ E-mail: sangeetamaharjan@gmail.com
}

\begin{abstract}
The mountain gap flow characteristics in and around the Chisapani mountain gap of Karnali River basin has been numerically simulated using the Weather Research and Forecasting (WRF) model to understand its spatial and temporal characteristics and its implications. The model was initialized with NCEP initial and boundary conditions to carry continuous integrations 168 long hours to identify the general flow field during early springtime. The river valley accumulates channels and flushes a narrow jet stream of about $10 \mathrm{~ms}^{-1}$ in speed and $500 \mathrm{~m}$ in its depth into the vast southern plain via Chisapani mountain gap during night and morning time whereas in the afternoon, the mountain feeds up-valley wind of about $4 \mathrm{~ms}^{-1}$ from the southern plain up into the Karnali River basin.
\end{abstract}

Keywords: Atmospheric modeling, coriolis acceleration, up-valley, downslopes and Karnali River valley.

\section{INTRODUCTION}

Thermally driven circulations develop regularly in mountainous terrain from existing temperature gradient in air masses if large scale flows are weak or absent (Whiteman 2000). These winds have decisive impact on local weather and microclimate affecting human life and the environment. These thermally driven winds can significantly enhance air pollution transport and dispersion (Hanna \& Strimaitis 1990, Banta et al. 1997, Raga et al. 1999, Whiteman, 2000, Alexandrova et al. 2003, Kitada \& Regmi 2003), fire propagation (Whiteman 2000), the formation of fog and convective precipitation (Smith et al. 1997), noise propagation (Heimann \& Gross 1999), and wind energy potential (Sturman 1987). The rich literatures on thermally driven wind system can be found in Defant (1951), Flohn (1969), McGowan and Sturman (1996) and Whiteman (2000). However, in the context of Nepal Himalaya where topographic undulations are very high, only a few studies that deals with the thermally wind systems in local scale are reported (Egger et al. 2000, Zängl et al. 2001, Kitada \& Regmi 2003, Regmi et al. 2003, Regmi, 2013, Acharya et al. 2014, Regmi 2014).

Karnali river valley is elongated and irregularly distributed valley extending from northwest to southeast, which is elevated at about 400 meters above mean sea level (AMSL). The characteristics terrain feature of the valley is the long chain of mountain ridges extending from northwest to southeast (hereinafter, LM ridge) whose average height is about 1000 meters. The LM mountain ridge acts as natural barrier walls for low-level air masses. The barrier wall has cleft forming into major mountain gap near Chisapani, (hereinafter Chisapani gap) along which the river Karnali flows downwards to the south. The river valley also sees maximum mountain crest height of 1800 meters to its north and the east within the study area. The Chisapani gap together with several other minor mountain gaps in LM mountain ridge allows channeling of air mass between southern plains and Nepal Himalayas.

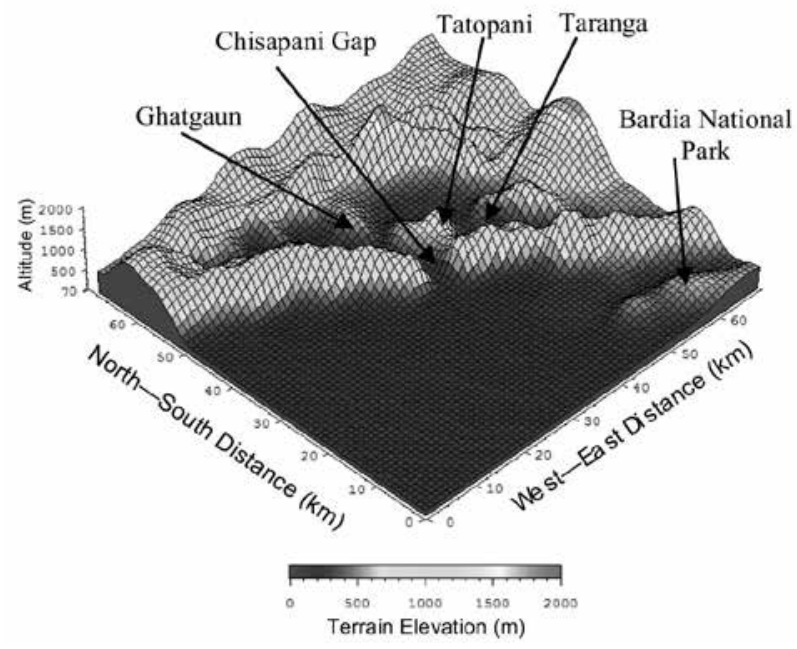

Fig. 1. Close-up view of Karnali River valley, Nepal, and its neighboring area in and around the Chisapani over which we will discuss the diurnal wind characteristics. 
The Chisapani Gap is said to be very windy and there has been much talk on exploiting prevailing wind resource for large-scale wind power generation. However, significant studies are not seen from this area. In this paper, we will present the diurnal variation and spatial distribution of wind in and around the Chisapani Gap in early springtime as revealed by numerical simulation of local flows using a meso-scale meteorological model.

\section{METHOLODGY}

WRF Modeling System version 3.4.1 (Michalakes et al. 2001, Skamarock et al. 2008) was configured for a triply nested two way interacting mesh having $52 \times 52$ horizontal grid points for outermost and inner domains with 9 and $3 \mathrm{~km}^{2}$ grid sizes, respectively, whereas the inner most domain was designed for $70 \times 70$ grid points of horizontal grid size $1 \mathrm{~km}^{2}$. For each of these domains 35 vertical levels were assigned. The lowest vertical level was set at 27 meters above the ground and the model top was set at $50 \mathrm{hPa}$ pressure level. All the three domains were centered at Chisapani, the southernmost confluence of Karnali River in Mid-Western Nepal.

A 168 hours long simulation was performed initializing with 6 hourly meteorological data from National Centers for Environmental Protection (NCEP) at the horizontal resolution and the 24-categories land use and 30 second terrain elevation data by United States Geological Survey (USGS) for the period of 0000 UTC 12 March 2013 to 0000 UTC 19 March 2013. The first 24 hours simulations were discarded to allow for model spin-up period. The physics options/schemes used in this calculation include WSM 3-class simple ice as microphysics parameterization, Unified NOAH land-surface, YSU Planetary Boundary Layer, RRTM long wave radiation schemes, and Dhudhia short wave radiation schemes etc. for all the domains whereas the Kain-Fritsch convective parameterization scheme was turned on only for coarse domain. The simulated result of 16 March 2013 has been chosen to describe evolution of diurnal wind in the Karnali river valley during early springtime.

\section{RESULTS}

Based on the experience of simulating wind systems over the middle hills of Nepal Himalaya in different parts of the country, we are encouraged to conclude that middle hills of Nepal Himalaya possesses very strong diurnal periodicity in local flows during winter and spring season. Like in other parts of the region, the Chisapani area as well executes very strong diurnal periodicity of local flows, i.e., there is little day-to-day variation and almost the same wind pattern has been predicted for this area during simulation period if we exclude the spin-up hours for the model (the first 24 hours of simulation). Among the days of simulation, we have chosen the day of 16 March 2013 for the discussion of diurnal wind characteristics over the Chisapani area as the representative day. Unavailability of observed wind data prevented us to appreciate validation of model predictions with observation. Given the reliable prediction made with WRF over extreme terrains of Nepal Himalaya compared to the present one (Regmi \& Maharjan 2013, Regmi 2014, Regmi 2013, Zängl et al. 2001), present simulation can be expected to be not much deviated from the reality and local people of the area are happy with the model predictions.

\section{Evolution of surface wind}

The near surface wind over the Karnali river valley, particularly, over the Chisapani Gap is discussed using the simulated horizontal wind from finest domain with $1 \mathrm{~km}$ horizontal grid resolution. The river valley receives the downslope winds from surrounding elevated hills and LM ridge throughout the nighttime (Fig. 2a-b). Similarly, the Chisapani gap organizes the strong outward gap flow, a narrow jet, whose speed may exceed $10 \mathrm{~ms}^{-1}$. This narrow jet flushes down into the vast southern plain that may encroach deep into the plain and beyond the Nepal territory.

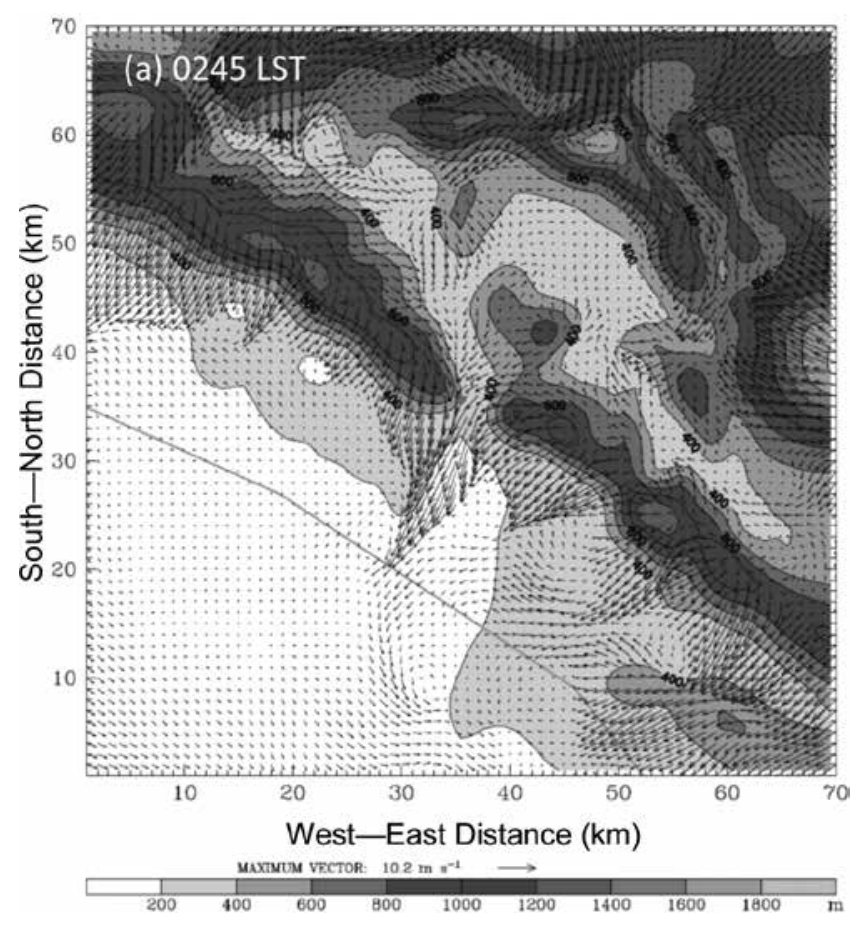



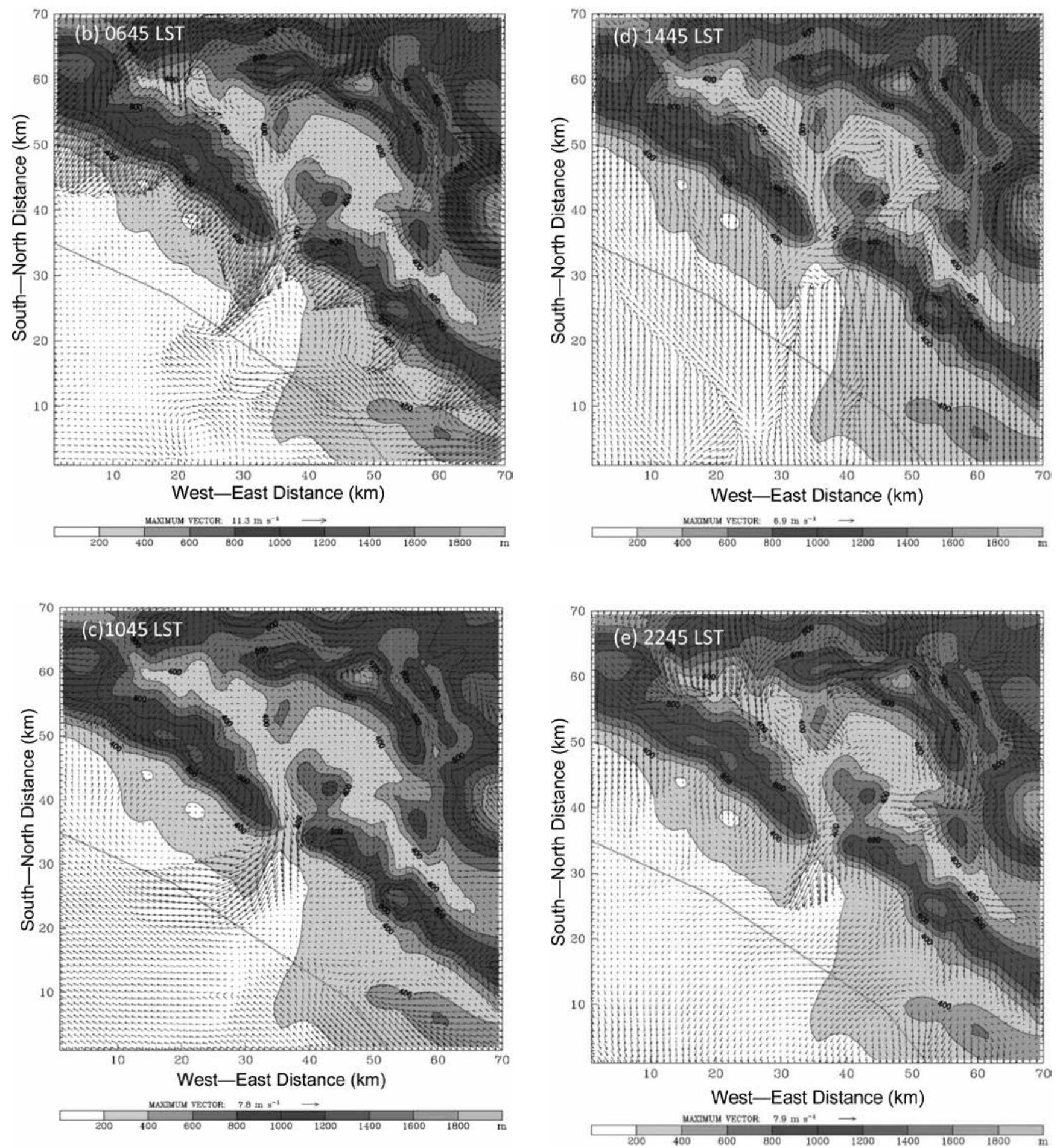

Fig. 2. Spatial distribution of wind over Karnali river valley at different time of a day. The solid orange line represents Nepal-India border in the south. Pink colored dot represents center of the study domain.

The jet flow generally appears to extend 10 to $20 \mathrm{~km}$ downstream. The narrow jet flow further flanked by weaker anti-cyclonic and cyclonic eddies in the west and southwest, respectively (Fig. 2a). Likewise, Bardia
National Park receives the strong downwind of about $7 \mathrm{~ms}^{-1}$ from the adjacent mountain ridges.

As morning progresses, the downslope winds over the mountainous areas weaken and hence the valley 
areas gradually tend to assume calmness. However, the narrow jet at Chisapani Gap persists and flushes into the southern plain but the nose of the jet turns left just at the Nepal-India border area (Fig. 2b-c). The anticyclonic deflection of gap wind noses have been reported in other parts of the world, particularly, when strong gap wind flushes into the oceans (Parmenter 1970, Stumpf 1975, Legeckis 1988, Schultz et al. 1997, Steenburgh et al. 1998). Anticyclonic deflection of gap wind over flat land surface is, thus, of particular interest and is worth to explore further since such phenomena, to the best of our knowledge, has not been reported so far. Clarke (1988) argues that anti-cyclonic flow curvature result from the Coriolis acceleration.

Cross sectional plots along mainstream of the narrow jet (not shown) suggests that the jet flow channeling through Chisapani Gap is about $500 \mathrm{~m}$ deep and the intensity of wind at gap entrance is rather weak compared to that at the exit in consistence with the research findings on the nature of the gap flows in Alpine valleys (Flamant et al. 2002, Overland 1984, Scorer 1952, Dorman et al. 1995) and also in Chivela Pass (Steenburgh et al. 1998).

The afternoon is marked by the reversal of wind flow at Chisapani Gap, i.e, mountain gap drives and feeds winds up into the Karnali River corridor from the southern plains. Thus intruding wind through the Chisapani Gap gets bifurcated at Tatopani and once again occurs at Ghatgaun (Fig. 2d and Fig. 1, for locations). The upvalley wind channeled by Chisapani Gap up into the Karnali River valley appears to be almost half in its speed compared to the night and morning time downvalley wind. The difference in up- and down-valley wind system appears to be exactly opposite to the nature of the up- and down-valley wind system over the Kali Gandaki valley in Mustang where the speed of daytime up-slope wind is as much as five times higher than the nighttime down-valley wind speed (Regmi 2014, Zängl et al. 2001). The flow pattern discussed above may persist until the evening with gradual decrease in its speed. As the evening progresses, the area in and around the Chisapani Gap becomes calm and then initiates the downslope winds (Fig. 2d) imitating the same pattern discussed earlier for nighttime thereby showing strong diurnal periodicity in the local flow pattern over the area.

\section{CONCLUSIONS}

The high-resolution numerical prediction of local flows in and around the southernmost confluence of the Karnali River valley has been made to understand the characteristic of the gap flow at the Chisapani mountain gap and its spatial and temporal distribution. The Karnali River valley generally remains calm during morning time with weak downslope wind in its surrounding mountains slopes. However, very strong gap wind prevails over the Chisapani mountain gap during night and morning time whose speed may remain more than $10 \mathrm{~ms}^{-1}$, particularly, during the late morning time. The Chisapani mountain gap channels a narrow jet stream of depth 500 $m$ and flushes down into the vast southern plain often churching beyond the Nepal-India border. The jet stream may undergo anti-cyclonical turning while proceeding downstream. In the afternoon, the Chisapani mountain gap pumps up the up-valley wind from the southern plain but with speed almost half of the nighttime downslope wind. The Chisapani mountain gap flow appears quite reverse to the flow pattern over the Kali Gandaki valley in Mustang in the sense that Kali Gandaki valley pumps up an extra ordinarily high (close to $20 \mathrm{~ms}^{-1}$ ) up-valley wind in the afternoon whereas nighttime downslope wind as much as 5 times lesser than the daytime up-slope wind.

The study has highlighted the necessity of detail study on evolution and dynamics of gap outflow over the mountain gap like at Chisapani of Karnali River valley distributed in the middle hill region of Nepal.

\section{ACKNOWLEDGEMENTS}

Authors acknowledge the support received from the Tribhuvan University and the University Grants Commission, Nepal.

\section{REFERENCES}

Acharya, S., Neupane, S., Chapagain, C., Shrestha, R., Acharya, P., Maharjan, S. and Regmi, R.P. 2014. Early Monsoon Time Local Flow Characteristics over the Hetauda Valley and its Implications. Journal of Institute of Science and Technology 19(2): 43-49.

Alexandrova, O.A., Boyer, D.L., Anderson, J.R., and Fernando, H.J.S. 2003. The influence of thermally driven circulation on PM10 concentration in the Salt Lake Valley. Atmospheric Environment 37: 421-437.

Banta, R.M., and Coauthors 1997. Nocturnal cleansing flows in a tributary valley. Atmospheric Environment 31: 2147-2162.

Clarke, A.J. 1988. Inertial wind path and sea surface temperature patterns near the Gulf of Tehuantepec and Gulf of Papagayo. Journal of Geophysical Research 93: 15491-15501.

Defant, F. 1951. Local winds. (ed.) Malone, T.F. Compendium of Meteorology, American Meteorological Society, Boston. 655-72p.

Dorman, C.E., Beardsley, R.C. and Limeburner, R. 1995. Winds in the Strait of Gibraltar. Quarterly Journal of the Royal Meteorological Society 121: 1903-1921. 
Egger, J., Bajrachaya, S., Egger, U., Heinrich, R., Reuder, J., Shakya, P., Wendt, H. and Wirth, V. 2000. Diurnal winds in the Himalayan Kali Gandaki Valley. Part I: Observations. Monthly Weather Review 128: 1106-1122.

Flamant, C., Drobinski, P., Nance, L., Banta, R., Hardesty, M., Pelon, J. and Richard, E. 2002. Gap flow in an alpine valley during a shallow south fohn event: Observations, numerical simulations and hydraulic analogue. Quarterly Journal of the Royal Meteorological Society 128: 1173-1210.

Flohn, H. 1969. Local wind systems. (ed.) Flohn, H. General Climatology, World Survey of Climatology 2, Elsevier, New York 2. 139-171p.

Hanna, S.R. and Strimaitis, D.G. 1990. Rugged terrain effects on diffusion. Atmospheric Processes over Complex Terrain (Meteorological Monographs) ed. Blumen, W. American Meteorological Society, Boston. 23(45) 109-143p.

Heimann, D. and Gross, G. 1999. Coupled simulations of meteorological parameters and sound level in a narrow valley. Applied Acoustic 56: 73-100.

Kitada, T. and Regmi, R.P. 2003. Dynamics of air pollution transport in late wintertime over Kathmandu valley, Nepal: as revealed with numerical simulation. Journal of Applied Meteorology 42: 1170-1798.

Legeckis, R. 1988. Upwelling off the Gulfs of Panama and Papagayo in the tropical Pacific during March. Journal of Geophysical Research 93: 15485-15489.

McGowan, H.A. and Sturman, A.P. 1996. Interacting multi-scalewind systems within an alpine basin, Lake Tekapo, New Zealand. Meteorology and Atmospheric Physics 58: 165-77.

Michalakes, J., Chen, S., Dudhia, J., Hart, L., Klemp, J., Middlecoff, J. and Skamarock, W. 2001. Development of a Next Generation Regional Weather Research and Forecast Model. Developments in Teracomputing: Proceedings of the Ninth ECMWF Workshop on the Use of High Performance Computing in Meteorology. (eds.) Zwieflhofer, W. and Kreitz, N. World Scientific. 269-276p.

Overland, J. 1984. Scale analysis of marine winds in straits and along mountain coasts. Monthly Weather Review 112: 2530-2534.

Parmenter, F.C. 1970: Picture of the month: a "Tehuantepecer". Monthly Weather Review 98: 479 .
Raga, G.B., Baumgardner, D., Kok, G., and Rosas, I. 1999. Some aspects of boundary layer evolution in Mexico City. Atmospheric Environment 3: 5013-5021.

Regmi, R.P. 2013. Springtime windstorm in the Kathmandu Valley and its Predictability. Journal of Institute of Science and Technology 18(2): 2836.

Regmi, R.P. 2014. Aviation weather hazards over the Jomsom Airport of Nepal as Revealed by Numerical Simulations of Local Flows. Journal of Institute of Science and Technology 19(1): 111-120.

Regmi, R.P. and Maharjan, S. 2013. Wind Power Density over the Kathmandu Valley and its Surrounding Areas. Journal of Institute of Science and Technology 18(1): 43-49.

Schultz, D.M., Bracken, W.E., Bosart, L.F., Hakim, G.F., Bedrick, M.A., Dickinson, M.J. and Tyle, K.R. 1997. The 1993 Superstorm cold surge: Frontal structure, gap flow, and tropical impact. Monthly Weather Review 125: 5-39.

Scorer, R. 1952. Mountain-gap winds; a study of surface wind at Gibraltar. Quarterly Journal of the Royal Meteorological Society 78: 53-61.

Skamarock, W.C., Klemp, J.B, Dudhia, J., Gill, D.O., Barker, D.M., Duda, M.G., Huang, X-Y., Wang, W. and Powers, J.G. 2008. A description of the advanced research WRF version 3. NCAR/TN475+STR, NCAR Technical Note. 7p.

Smith, R. and Coauthors 1997. Local and remote effects of mountains on weather: Research needs and opportunities. Bulletin of the American Meteorological Society 87: 877-892.

Steenburgh, J.W., Schultz, D.M. and Colle, B.A. 1998. The structure and evolution of gap outflow over the Gulf of Tehuantepec, Mexico. Monthly Weather Review 126: 2673-2691.

Stumpf, H.G. 1975. Satellite detection of upwelling in the Gulf of Tehuantepec, Mexico. Journal of Physical Oceanography 5: 383-388.

Sturman, A.P. 1987. Thermal influences on airflow in mountainous terrain. Progress in Physical Geography 11: 183-206.

Whiteman, C.D. 2000. Mountain Meteorology. Oxford University Press, $171 \mathrm{p}$.

Zängl, G., Egger, J. and Wirth, V. 2001. Diurnal winds in the Himalayan Kali Gandaki valley. Part II: Modeling. Monthly Weather Review 129: 10621080. 